\title{
Elizabeth Choinski
}

\section{What are you? \\ Identifying librarians' academic rank}

$\mathbf{T}$ he academic library where I work is at a typical doctoral/research university in the United States. In such institutions, faculty are usually granted tenure based on a proscribed set of guidelines. At many of these institutions, librarians hold tenure-track faculty positions and are held to a similar standard as their teaching colleagues. It is typical for both teaching faculty and librarian faculty to have their tenure and promotion dossiers evaluated by reviewers from outside the home university and who are tenured and promoted to the level to which the candidate has applied. Does that sound familiar? Does it also sound familiar that identifying librarians to serve outside evaluators is often the bottleneck in an otherwise smooth tenure and promotion process?

As an academic librarian at the rank of professor, one of my professional duties is to serve as a member of my library's tenure and promotion advisory committee. This committee is responsible for writing a summary and evaluation of a candidate's record in librarianship, service, and research/creative achievement based on the candidate's dossier, annual evaluations, and letters from external evaluators.

At the time that they submit a tenure and/or promotion dossier, our candidates are required to submit the names and contact information of possible external evaluators. The committee has the task of identifying additional outside evaluators who are not on the candidate's list so that we can solicit some evaluators known to the candidate and some who are not.

And there's the rub. How do we identify outside evaluators who are tenured (or the equivalent at their institution) and who are of a rank at the same level (or higher) to which the candidate is applying? How do we do this when the committee members may not be familiar with the candidate's areas of expertise? The roadblocks to identifying possible external evaluators are surprising, given that we are in the information business.

Here's a fictitious yet realistic scenario. Our advisory committee has three members. One of them is a science librarian, one is a business librarian, and one is an archivist. We are all full professors, and we are the advisory committee for a candidate's application to full professor. The candidate is a metadata librarian and has submitted four names of possible external evaluators. We select two of those names and then we must find two more who are not on our candidate's list.

Of course, sometimes it is easy enough to ask colleagues at other institutions if they know of people who can fill our need as evaluators. We know our in-state colleagues fairly well, and we are all willing to do each other a favor. We also keep in mind colleagues at other institutions for whom we have served as external evaluators, and we contact them asking for help.

But sometimes our networking is not enough. So we Google. We Google a lot. We are able to identify one or two names of people who we know are metadata librarians at an equivalent rank to professor. Oops, one of them is already on our candidate's list.

Elizabeth Choinski is science librarian and professor at the University of Mississippi Libraries, email: ulemc@ olemiss.edu

(c) 2016 Elizabeth Choinski 
We go back to the drawing board. We visit the Academic Librarian Status wiki ${ }^{1}$ to identify academic libraries where librarians have faculty status. We use that information to go to the staff directories at these libraries. Alas, most of them do not post their faculty status next to librarians' names or anywhere on the library's website. We identify possible candidates and Google some more, trying to find a CV or a LinkedIn page for individuals where they list their status. Maybe we get lucky. Many times, we don't.

We struggle onward until we manage to identify a couple of people who fit our needs, who are willing to serve, and who can send us back a thoughtful evaluation within the required time frame. Sometimes the process of finding a suitable evaluator can take weeks. This is especially true when we are looking for librarians at the rank of full professor, since there are many fewer professors than associate professors in libraries.

I know that librarians at my institution are not alone in finding this scenario familiar, time-wasting, and just plain aggravating. But there are some easy solutions that I think can alleviate the aggravation and cut down the amount of time spent just trying to identify external evaluators.

The first is for academic libraries to post their tenure information on the Academic Librarian Status wiki. It's free, it only takes a minute, and it is a potential gold mine of information. Even more helpful is to have individuals' academic ranks listed in every academic library's staff directory or somewhere on the library's website. I'm baffled as to why this isn't more common already. We have worked hard to achieve success. We want to be treated with the same respect as teaching faculty. We want to signal to prospective employees the nature of our work. It seems only natural to me that we would want to display our academic ranks.

If you are a librarian with faculty status, won't you please make sure that information is available somewhere online for your colleagues to find? If you are an administrator, please consider listing academic rank in your staff directory as a matter of policy. If a large number of libraries would participate in these relatively simple steps, it would really help to unclog the pesky bottleneck in the tenure and promotion process.

\section{Note}

1. "Academic Librarian Status." wikispaces. com, accessed February 11, 2016, http:// academic-librarian-status.wikispaces.com/. n

\section{Upcoming ACRL e-Learning}

ACRL is offering a variety of online courses and webcasts this winter/spring. Upcoming topics include:

Recent Developments in Fair Use (Online Course: March 21-April 15, 2016)

Engaging the Digital Humanities: Collaborating throughout the Research Lifecycle (Webcast: March 23, 2016)

Modern Pathfinders: Easy Techniques to Make Better Research Guides (Webcast: April 6, 2016)

Teaching at the Intersections: Aligning Scholarly Communication and Information Literacy in the One-Shot Library Instruction Session (Webcast:April 7, 2016)

No Librarian Left Behind: Building a Structured Mentoring Program For Organizations of All Sizes (Webcast:April 27, 2016)

Make the most of your professional development dollars through ACRL's e-Learning Frequent Learner Program. Register for three e-Learning courses or Webcasts and receive a fourth free.

Visit the ACRL e-Learning website at www. ala.org/acrl/onlinelearning for complete details and a full listing of upcoming ACRL e-Learning events. 